\title{
Russian Prerevolutionary Historiography about Medieval Individual Religiosity
}

\author{
D. I. Weber
}

For citation: Weber D. I. Russian Prerevolutionary Historiography about Medieval Individual Religiosity. Vestnik of Saint Petersburg University. History, 2018, vol. 63, issue 4, pp. 1277-1288. https://doi. org/10.21638/11701/spbu02.2018.416

The article is devoted to a number of Russian studies regarding the medieval religiosity of the individual. As a rule, the development of this direction is associated with the Annales school, which in the $20^{\text {th }}$ century had a serious influence on various historical research aspects not only in Europe. In the framework of this article, the attention is focused on the research work of Guerrier, Karsavin, Kudryavtsev, and Bitsilli. In the national historical scholarship at the time, the term "mentality" was absent. However, such concepts as "consciousness", "religiosity" were repeatedly used. The researchers sought to explain not only the formation and significance of this phenomenon in the context of social history, but also paid attention to its cultural specificity, in particular, referring to the symbolism of the medieval individual's thinking. Some of the Russian historians of medieval European history the late $19^{\text {th }}-$ first decade of the $20^{\text {th }}$ century made a significant contribution to the work on the subject. The interest in the man in history emerged in Russian medieval studies of the time. It is important to note that in analyzing the religiousness of an individual, Russian scholars focused on the views of certain outstanding personalities: as a rule, those of the elite, the chroniclers and the theologians. Further development of research in this direction was interrupted by political events and the later formation of a new historical pattern. Russian scholarship addressed this problem again only in the 1980s.

Keywords: religiosity, Karsavin, Kudryavtsev, Bitsilli, Guerrier, Middle Ages.

\section{Российская дореволюционная историография о средневековой индивидуальной религиозности}

\section{Д. И. Вебер}

Для цитирования: Weber D. I. Russian Prerevolutionary Historiography about Medieval Individual Religiosity // Вестник Санкт-Петербургского университета. История. 2018. Т. 63. Вып. 4. C. 1277-1288. https://doi.org/10.21638/11701/spbu02.2018.416

В статье предполагается обратить внимание на изучение индивидуальной религиозности в российской историографической традиции рубежа XIX-XX вв. В исторической

Dmitriy I. Weber - PhD, Assistant, St. Petersburg State University, 7-9, Universitetskaya emb., St. Petersburg, 199034, Russian Federation; d.veber@spbu.ru

Дмитрий Иванович Вебер - канд. ист. наук, ассистент, Санкт-Петербургский государственный университет, Российская Федерация, 199034, Санкт-Петербург, Университетская наб., 7-9; d.veber@spbu.ru

This article was prepared for the RSF project N. 16-18-10083 "The study of religion in social and cultural context of the epoch: the history of religious and intellectual history of Russia in the first half of XIXXX centuries".

(c) Санкт-Петербургский государственный университет, 2018 
науке существуют различные подходы к изучению прошлого. Они отличаются методологическими основаниями, объектом и предметом исследований. Наличие разных национальных школ привносит определенную специфику в используемые подходы. Одним из проблемных полей исследования средневековой культуры является изучение специфических особенностей духовного мира индивидуума. В начале XX в. в отечественной историографической традиции заметно оживление интереса к данной проблематике. Это нашло выражение и в появлении новых терминов, таких как «религиозный фонд», «средний человек». Изучение индивидуальной религиозности было связано с изучением не только социальной среды, в которой эта религиозность проявлялась, данный аспект рассматривался также с точки зрения связи со средневековым символизмом. В статье обращается внимание на труды В.И. Герье, П.Н. Кудряцева и, в особенности, Л. П.Карсавина и П.И. Бицилли. В отечественной исторической науке того времени термин «ментальность» отсутствовал. Взамен неоднократно встречаются такие понятия, как «сознание», «миросозерцание», «религиозность». Исследователи стремились не только объяснить формирование и значение этого феномена в контексте социальной истории, но и обращали внимание на культурную специфику этого явления, в частности говоря о символизме мышления средневекового индивидуума. Важность изучения данного аспекта заключалась не в одном стремлении понять средневековое общество, но и проследить эволюцию к Новому времени. При анализе религиозности отдельного индивидуума акцент смещается на взгляды отдельных личностей, как правило, представителей знати, хронистов, богословов. Развитие исследований в этом направлении было прервано политическими событиями и формированием впоследствии новой исторической парадигмы, что, в свою очередь, стало серьезным препятствием созданию отечественной школы, аналога французской, которая занималась бы изучением средневековой религиозности индивидуума.

Ключевые слова: религиозность, Карсавин, Кудрявцев, Бицилли, Герье, Средние века.

There are various approaches to the study of the past in historical scholarship. They differ by methodological background, by the object and subject of study, which, in their turn, impact the methodological basis. Works on the history of medieval studies can be provisionally divided into two related categories: "history of ideas" and "history of personalities," in other words, the history of concepts and the history of scholars. These works come in different genres and are of different lengh. Various national schools bring their own flavor to the approaches used. When analyzing the study of the history of mentality, it seems most expedient to look at the history of ideas. One of the problem fields in studying medieval culture is the exploration of specific characteristics of the spiritual world of an individual. The drive to study that perception of the world is the hallmark of historic methodology of the $20^{\text {th }}$ century and enables us to speak of its distinct aspects. However, Soviet academics mostly focused on economic history, in view of their Marxist methodology. This makes the emergence of interest in the study of personal religiousness at the turn of the $20^{\text {th }}$ century, and the trend itself, so much more noteworthy.

Soviet scholarship was ambiguous in its treatment of the achievements of pre-revolution historians. The works of most of them were forgotten, some very harshly criticized. The criticism traditionally concerned their refusal to deal with the idea of class struggle, fascination with religious and mystical agenda, and the fact that history of culture and history of religion shied away from social and political roots ${ }^{1}$. Overall, it should be noted

1 Vaynshteyn O.L.: 1) Istoriografiia srednikh vekov v sviazi s razvitiem istoricheskoi mysli ot nachala srednikh vekov do nashikh dney. Moscow, 1940;2) Istoriia sovetskoi medievistiki. Leningrad, 1968; Alpa- 
that until the end of the 1960s no one had even posed the problem of studying the rise of the history of mentality as a separate field of study in historiography, while the problem of studying personal religiousness, even if it was considered, was only looked at in specifically sociological terms ${ }^{2}$. The works of the 1970s-1980s put forward a radically different perception of the legacy of pre-revolution scholars. Not only was these scholars' contribution to the development of Russian historiography as a whole, but their contribution to the history of mentalities viewed positively ${ }^{3}$. This development continued in the 1990s. One of the leading tendencies of the recent years has been the attempt to evaluate the entire experience of studying this area, including the Soviet period ${ }^{4}$.

In the second half of the $19^{\text {th }}$ century, historiography in Russia went through a special and interesting period of growth. The era of the Great Reforms, especially - the peasant reform, had a huge impact on the scholarly endeavors of historians in the second half of the $19^{\text {th }}$ century. The interest in the history of peasantry grew, including the history of European peasantry. At the time, the history of Western-European Middle Ages emerged as a separate field of historical studies.

Separating medieval studies into a special branch of historical research was, to a certain degree, based on the desire of historians to understand and come to grips with the international experience on the agrarian issue, "to find an answer to the burning questions

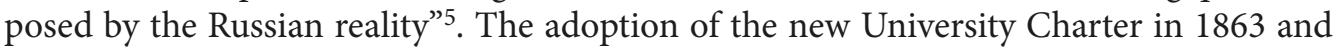
the new Law on Censorship in 1865 had the most direct influence on historiography in the 1860s and 1870s. The Charter gave autonomy to universities and expanded opportunities for going abroad. The Law on Censorship reduced censorship to some extent. All this nurtured "a lesser constraint of the thought and word and expanded the circle of historical topics" 6 . This is evidenced, in particular, by the discussion that unfolded in the works devoted to medieval religiousness ${ }^{7}$.

tov M. Krizis russkoy medievistiki v nachale XX veka // Problemyi istoriografii. Voronezh, 1960. P.23-27; Gutnova E. V. Sorok let sovetskoy medievistiki i ee ocherednyie zadachi // Srednie veka. 1957. Iss. 10. P.3-24.

${ }^{2}$ See, for example: Shakhnovich $M$. The activity of the commission on the history of religion of the Communist Academy (Moscow, 1928-1930) and the study of religiosity in USSR // Religiski - filozofiski raksti. Riga, 2017. Vol.XXIII. P.9-25; Seleznev R. Mentalnaia istoriia Srednevekov'ia v issledovaniiah pervyikh russkikh medievistov vtoroy polovinyi XIX v.: istoki i zarozhdenie problematiki // Rossiia i mir: panorama istoricheskogo razvitiia: sbornik nauchnyikh statey, posviaschennyiy 70-letiyu istoricheskogo fakulteta Uralskogo gosudarstvennogo universiteta im. A. M. Gorkogo. Ekaterinburg, 2008. P. 48-56.

3 Gurevich A. Ya.: Kategorii srednevekovoi kulturyi. Moscow, 1972; Problemy srednevekovoi narodnoi kulturyi. Moscow, 1981; Ershova V. M. Dobiash-Rozhdestvenskaya O. A. Leningrad, 1988.

${ }^{4}$ Horuzhiy S. S. L. P. Karsavin. Moscow, 2012; Yastrebitskaya A.L. Povsednevnost i materialnaia kultura srednevekovia v otechestvennoi medievistike // Odissey. Chelovek v istorii. 1991. P. 84-103; Kupriyanov A. I. Istoricheskaia antropologiia v Rossii: problemyi stanovleniya // Istoricheskie issledovaniia v Rossii (tendentsii poslednikh let). 1996. № 4. P.366-385; Krom M. M. Istoricheskaia antropologiia. Moscow, 2004; Shuvalov V. Sotsialno-psihologicheskii aspekt izucheniia istorii v rossiyskoi istoriografii poslednei treti XIX - pervoi poloviny XX v. Moscow, 2001; Seleznev R. Mentalnaia istoriia Srednevekov'ia v issledovaniiah pervyikh russkikh medievistov vtoroy polovinyi XIX v.: istoki i zarozhdenie problematiki. P. 48-56; Gayva E. V. Simvolizm zapadnoevropeyskoy srednevekovoy myisli v otechestvennoy istoriografii XX veka: dis. ... kand. ist. nauk. Omsk, 2011 and others.

${ }_{5}$ Mogilnitskiy B. G. Politicheskiye i metodologicheskiye idei russkoy liberalnoi mediyevistiki serediny 70-kh godov XIX v. — nachala 900-kh godov. Tomsk, 1969. P. 67.

${ }^{6}$ Buzeskul V.P. Vseobschaia istoriia i ee predstaviteli. Vol. 1. Leningrad, 1929. P. 137.

7 Grevs I. M. Lik i dusha srednevekovya (po povodu vnov vyishedshih russkih trudov). Rassuzhdeniya po povodu treh knig - Dobiash-Rozhdestvenskaya O. A. Zapadnaia Evropa v srednie veka. Petrograd, 1920; Karsavin L. P. Kultura srednikh vekov. Petrograd, 1918; Bicilli P. M. Elementi srednevekovoi kulturi. Odessa, 
T.N.Granovsky, P.N.Kudryavtsev, V.I.Guerrier and others are believed to have been the founders of national medieval studies. At the time certain trends in the studies of Western-European Middle Ages became apparent: at first, the social-economic ones (P. G. Vinogradov, M. M. Kovalevsky, I. V.Luchitskiy, N.I. Kareev and others); later on the religious ones (V.I. Guerrier, I. M. Grevs and others) ${ }^{8}$. As far back as the discussion on the Renaissance era, P.N.Kudryavtsev introduced the idea of the dynamic nature of the human mind in history'; in other words, the idea that became the foundation of methodology of any historian of mentality. The scholar emphasized that the mind of a medieval person differed from that of a person of modern times ${ }^{10}$.

Naturally, we will not find the term "mentality" in Russian historiography of that time; however, even back then, scholars were interested in the inner world of an individual $^{11}$, and such terms as "mind" and "worldview" were used to describe it. The latter term appeared, for example, in the works of V.I. Guerrier ${ }^{12}$. There is an opinion in historiography that he was a historian of culture, of ideas ${ }^{13}$, and the founder of the "religious" and "religious and mystical" line of research in pre-revolution medieval studies ${ }^{14}$. Such a description of the scholar is due to his interest in the history of the church and Christianity. Most likely, his interest in the subject of medieval worldview grew, in many aspects, under the influence of European scholars, in particular, the works by G. Eiken and P. Laurent ${ }^{15}$. Guerrier also believed that the church had played a crucial role in forming the medieval worldview ${ }^{16}$. In his opinion, the medieval worldview of the individual was based on the principles of asceticism and world power ${ }^{17}$. The originators of these principles were the clergy and popes, represented, for example, by Saint Augustine of Hippo, Bernard of Clairvaux, Pope Innocent III and others ${ }^{18}$. These two principles were antagonistic to each

1919// Annali. 1922. N 1. P. 21-41. The Grevs's recension to Karsavin's work see more: Nauchno-istoricheskiy zhurnal. 1913. N 1; Egorov D. N. Srednevekovaia religioznost i trud L. P. Karsavina // Istoricheskie izvestiia. 1916. N 2. P. 85-106; Polemika mezhdu L. P. Karsavinym i D. N. Egorovyim // Istoricheskie izvestiia. 1916. N 3-4. 148-157; Kareev N.I. Obschiy religioznyiy fond i individualizatsiia religii (po povodu "Osnov" L. P. Karsavina i "Valdenskogo dvizheniya" A. G. Vulfiusa) // Russkie zapiski. 1916. N 9. P. 195-225; Weber D. The Religious Studies on the Eve of Totalitarianism. The Issue of Reformation // Religiski-filozofiski raksti. Vol.XXIII. Riga, 2017. P. 72.

${ }_{8}$ Mogilnitskiy B.G. Politicheskie i metodologicheskie idei russkoi liberalnoi mediyevistiki serediny 70-kh godov XIX v. — nachala 90-kh godov. Tomsk, 1969. P. 166.

${ }_{9}$ Kudryavtsev P. N. Lektsii. Sochineniya. Moscow, 1991. P. 12.

10 Ibid. P.7.

11 The term "mentality" was introduced by the French ethnologist and socio-anthropologist L. Lévy-Bruhl, who studied pre-logical thinking and "collective representations" (or "mentality") of the so-called "primitive peoples". A characteristic feature of this mentality, according to L. Levy-Bruhl, was its inexplicability with the help of ordinary logic and common sense, "mysticism", the implication of all to universal beliefs or delusions. See: Lévy-Bruhl L. La mentalité primitive. Paris, 1925.

12 Guerrier V.: Ocherki razvitiya istoricheskoy nauki. Moscow, 1865; Katarina Sienskaya // Vestnik Evropy. 1892. Vol. 5, N 9-10.

13 Gutnova E. Istoriografiia istorii srednikh vekov. Moscow, 1985.

14 Buzeskul V. Vseobschaya istoriya i ee predstaviteli. Vol. 1. Moskow, 1929. P. 153.

15 Eicken H.von. Geschichte und System der mittelalterlichen Weltanschauung. Stuttgart, 1887; Laurent P. Études sur l'histoire de l'humanité. Christianisme. T. 4. Gand, 1855.

16 On Guerrier's ideas about the conception of Eucken, see: Guerrier V:: Srednevekovoe mirovozzrenie. Ego vozniknovenie i ideal // Vestnik Evropy. 1891. N 1. P.172-196; Srednevekovoe mirovozzrenie. Ego vozniknovenie i ideal // Ibid. N 2. P.751-781; Srednevekovoe mirovozzrenie. Ego vozniknovenie i ideal // Ibid. N 3. P. 5-29; Srednevekovoe mirovozzrenie. Ego vozniknovenie i ideal // Ibid. N 4. P. 495-552.

17 Guerrier V. Zapadnoe monashestvo i papstvo. Moscow, 1913. P.2

18 Guerrier V. Katarina Sienskaya. N 10... P. 479. 
other, which was evident in the church activities ${ }^{19}$. On the one hand, the Church called for leading an ascetic life and forsaking worldly vanities, yet at the same time it actively fought for power ${ }^{20}$. Analyzing these components, the scholar argued not only with Eicken, but also with Laurent ${ }^{21}$. The author discovered yearning and searching for the Divine and symbolic in daily surroundings, intrinsic in the man of that time, in the ideology of Christianity and in the daily life of the Middle Ages ${ }^{22}$.

P. N. Kudryavtsev was one of the first among the national scholars who put forward the idea of the dynamic nature of the human mind in history, the idea that subsequently laid the foundation for the methodology of any historian of mentality. He was emphatic in his opinion that the mind of a medieval man was just as different from that of a man of Modern Times as the feudal system differs from the capitalist one ${ }^{23}$. The evolution from the Middle Ages to the Modern history is noticeable first and foremost in the minds of the people, according to the scholar ${ }^{24}$.

Kudryavtsev is consistent in his conclusions, and his lectures tell us that a man of the Modern history is governed by other motives or "incentives" than a Medieval man. One of the characteristics that differentiates a medieval man from a modern man is the widened horizon of the latter, which allowed him to "give his thought absolutely new ways and spaces"25. Kudryavtsev's meditations on two distinct cultures that were found in medieval society also deserve some attention. These were the elite culture (the "best minds") and the folk culture (the "masses"). Kudryavtsev believed that one of the achievements of the Renaissance Era was that elements of the elite culture penetrated through to the masses; that said, it was mostly the cultural legacy of antiquity that was understood as these "elements" 26 . Nonetheless, P.N. Kudryavtsev did not make a special attempt to study folk culture. At the same time, we cannot overlook the important fact that it was in the works of national medieval scholars that the phrase "Medieval Man" emerged, and an interest in his worldview came to life long before the works of the famous French historians M. Bloch and L. Febvre.

However, as far as studying an individual and his religiousness is concerned, we believe that attention should first and foremost be accorded to the works of L.P.Karsavin and P.M.Bitsilli ${ }^{27}$. Their research was ahead of the famous French Annales

19 Ibid. P. 483.

20 Guerrier V. Zapadnoe monashestvo... P. 4.

${ }^{21}$ Guerrier V. Srednevekovoe mirovozzrenie. N 1. P.172-196; Ivanova T. Dilemmi zapadnoevropeyskogo srednevekovya v istoricheskoi kontseptsii V. I. Guerrier // Uchenyie zapiski Kazanskogo gosudarstvennogo universiteta. 2009. Vol.151, book 2, part 1. P. 150.

22 Guerrier V.I. Ocherki razvitiia istoricheskoi nauki. Moscow, 1865. P. 10-11.

23 Kudryavtsev P. N. Lektsii. Sochineniia. Moscow, 1991. P.7.

24 Ibid. P. 8.

25 Ibid. P. 10.

26 Ibid. P. 12.

27 Karsavin L.P.: 1) Ocherki religioznoy zhizni v Italii XII-XIII vekov. St. Petersburg, 1912; 2) Monashestvo v srednie veka. St. Petersburg, 1912; 3) Mistika i ee znachenie v religioznosti srednevekovya // Vestnik Evropy. 1913. N 8. P.118-135; 4) Simvolizm myshleniya i ideya miroporyadka v srednie veka. XIIXIII vv. // Nauchnyiy istoricheskiy zhurnal. 1914. Vol. 1, iss. 2. P. 10-28; Osnovy srednevekovoi religioznosti v XII-XIII vekah, preimuschestvenno v Italii. St. Petersburg, 1915; Vvedenie v istoriyu (Teoriya istorii). Petrograd, 1920; Filosofiya istorii. Petrograd, 1923; Bitsilli P.M.: Salimbene. Ocherki italyanskoi zhizni XIII v. Odessa, 1916; Elementi srednevekovoy kulturi. Odessa, 1919; Ocherki teorii istoricheskoy nauki. Praga, 1925; Frantsisk Assizskiy i problema Renessansa // Sovremennyie zapiski. 1927. N 30. P.520-537; Mesto Renessansa v istorii kulturyi. Sofiya, 1933. 
School ${ }^{28}$. Nevertheless, their ideas were strongly criticized. Soon after Karsavin's Master's thesis was published, it called forth critical commentary ${ }^{29}$. I. M. Grevs, for instance, accused Karsavin of fascination with the mystical and departure from academic explanation ${ }^{30}$.

In order to describe the historical concepts of L. P. Karsavin and P.M. Bitsilli, we need to begin with the principles of their historical methodology. The methodological preferences of L.P. Karsavin are fully presented in his article "Introduction to History", and those of P. M. Bitsilli can be found in his work Elements of Medieval Culture cited above. From the point of view of L.P. Karsavin, the subject of the science of history is the study of humankind in its social development. "Social development" is thought of widely as socially political, economic and spiritually cultural. L. P. Karsavin unequivocally states that social activity of a man is always a derivative of his psychological development, of the needs of his "Ego." Thus, the task of a historian is to comprehend the socially psychological development of humankind. P.M. Bitsilli partially agrees with him on this ${ }^{31}$. They believed that the human mind has no less impact on the objective factors of historical development than vice versa, in other words, there is inter-influence and, consequently, a historian must take into account both the objective and the subjective factors.

The similarity of views of L. P. Karsavin and P. M. Bitsilli can also be seen in the requirements that both historians had for history of the everyday and material culture. Karsavin, in particular, noted the importance of studying this component of society from the point of view of its symbolism ${ }^{32}$. P. M. Bitsilli agrees with him ${ }^{33}$.

In the opinion of L.P. Karsavin, the key feature of an "average religious person" was the contradictory nature of concepts, feelings and relations that manifested itself in the intermixture of various religious ideas in the mind of an individual: 1. Pagan polytheism existed side by side with unlimited dominance of the official dogma: concepts of a multitude of anthropomorphic spirits, such as household gods and spirits appearing on a daily basis, were strong in the public opinion. 2 . The duality of the medieval mind: the concepts of God's grace and impurity, the constant struggle between good and evil (God and devil, saints and demons). 3. Monotheism: the concept of a single all-mighty God similar to an earthly emperor ${ }^{34}$.

Karsavin called the inclination of the medieval man to explain certain miracles by divine intervention in earthly life the "idea of world order." A miracle, in the opinion of

${ }^{28}$ Kaganovich B. S. Bitsilli P. M. i ego kniga "Elementi srednevekovoy kulturi" // Bitsilli P. M. Elementy srednevekovoy kulturyi. St. Petersburg, 1995; Shkuratov V. A.: Istoricheskaia psihologiia. Moscow, 1997; Sotsialno-psihologicheskiy aspekt izucheniya istorii v rossiyskoy istoriografii posledney treti XIX - pervoy polovinyi XX vv. Moscow, 2001; Yastrebitskaya A. Povsednevnost i materialnaya kultura...

29 Grevs I. M. Novyiy trud po istorii srednevekovoy Italii // Zhurnal Ministerstva Narodnogo Prosvescheniya. 1913. N 12. P. 336-405; Dobiash-Rozhdestvenskaya O. A. Religioznaia psihologiia srednevekovia v issledovaniiakh russkogo uchenogo // Russkaia mysl'. 1916. N 4. P.22-28; Kareev L. P. Po povodu odnogo issledovaniia srednevekovyih nauchnyih dvizheniy // Russkoe bogatstvo. 1913. N 6. P.333-340.

${ }^{30}$ Grevs I.M. Chelovek s otkryityim serdtsem. Avtobiograficheskoe i epistolyarnoe nasledie I. M. Grevsa (1860-1941). St. Petersburg, 2004. P. 297.

31 Bitsilli P. M. Elementi srednevekovoy kulturi... P. 132.

32 Yastrebitskaya A. L. Povsednevnost i materialnaia kultura... P. 89.

${ }^{33}$ Kaganovich B. S. Bitsilli P. M. i ego kniga... P. XIX. About the discussion between P. Bitsilli and L. Karsavin see more: Vasileva M. A. Srednevekovaia Italia i spor o "srednem cheloveke": polemika P. M. Bitsilli s L. P. Karsavinim // Rossiya - Zapad - Vostok. Literaturnyie i kulturnyie svyazi. N 2. St. Petersburg, 2014. P. 50-64.

${ }^{34}$ Karsavin L.P. Osnovy srednevekovoi religioznosti v XII-XIII vekah, preimuschestvenno v Italii // Karsavin L. P. Sobranie sochineniy. Vol. 2. St. Petersburg, 1997. P. 45. 
some theologians, was a violation of the natural order, an intervention of the metaphysical power, since "God acts without nature, sometimes in the nature, sometimes above nature" (Hugh of Saint Victor $)^{35}$. Thus, the emergence of the "idea of world order" was related to the intertwining of the divine and the earthly worlds in the mind of a medieval man.

For a medieval man, references to God, or to acts of Divine Power, made all miracles logical and understandable or lawfully consistent with the real world, so they filled their niche in the everyday life and formed the "idea of world order". Karsavin connected it to a peculiarity of the medieval mind, the essence of which was not the lack of concepts of natural science and not their substitution with metaphysical explanations, but in their interrelationship ${ }^{36}$.

The interweaving between the real world and the divine gave rise to an extremely notable phenomenon of medieval religiousness - mysticism. Analyzing the works of such famous mystics as Bernard of Clairvaux, Hildegard, William of Champeaux, Hugh of Saint Victor, L. P. Karsavin drew conclusions on the nature of mysticism.

L.P. Karsavin was certain that the significance of mysticism for a religious person was in the opportunity to reach the Divine knowledge on their own by understanding the essence of God. The core of mysticism is in the contact of the soul with the metaphysical. Thus, a mystic is a person who tries to understand God through a special internal state (mystical trance). Since "the human mind is not capable of understanding the Divine; the true insight can only be reached in contemplation, in mystical trance" ${ }^{37}$. Karsavin thought that one should not limit medieval mysticism by the trance of the greatest mystics. The so-called "vulgar mysticism," worldly and common, closely tied to the church and its rites, was no less popular. Nonetheless, even "vulgar mysticism" had an element of danger for the church, such as various folk beliefs, superstitions, household and woodland spirits, fortunetelling and astrology. That is precisely the manifestation of dualism in a medieval man, this combination of Christian dogma and elements of pagan beliefs.

One of the forms of manifestation of mysticism in the mind of a medieval man was symbolism, in which, according to L. P. Karsavin, not only the religious, but also the secular, worldly life of the time was immersed. Symbolism was one of the important features of the medieval worldview. It was especially characteristic of its religious component. "Symbolizing" means assigning the Divine meaning, that is, the true meaning, to anything; the meaning that is supposed to explain to a layman the earthly purpose of a given thing or phenomenon. The symbolic interpretation of the cult was not viewed as a contrivance attached to thing; the true essence of a thing was not in its earthly name, but in its symbol ${ }^{38}$.

Karsavin focused on peculiarities of the religious mind. It is also important to note that, according to the traditions of historiography of the early $20^{\text {th }}$ century, he did not attempt to lay bare the religiousness of the "masses" of medieval Europe. Karsavin built his research on the analysis of "typical" and "genius" individuals of the time. For a study of religiousness of the $12^{\text {th }}-13^{\text {th }}$ centuries, the heyday of medieval religiousness, a "typical stratum" was the clergy and educated laity that gravitated toward $\mathrm{it}^{39}$.

${ }^{35}$ Karsavin L. P. Osnovy srednevekovoi religioznosti... P. 47.

36 Ibid. P. 67.

37 Karsavin L.P. Mistika i ee znachenie v religioznosti srednevekovya // Karsavin L. P. Sochineniia. Moscow, 1993. P. 19.

38 Karsavin L. P. Monashestvo v Srednie veka. Moscow, 1995. P. 163.

39 Karsavin L. Osnovy srednevekovoi religioznosti v XII-XIII vekakh, preimuschestvenno v Italii. St. Petersburg, 1915. P. 29. 
Nevertheless, in disclosing the essential features of a medieval mind, L. P. Karsavin noted several times that the mystical and symbolic direction of a medieval mind was not only a feature of the educated. For common people, manifestations of mysticism and symbolism took the form of folk superstitions, fortunetelling, omens, astrology and belief in woodland and household spirits ${ }^{40}$. Attempts of the church to overcome the belief of the masses in pagan gods met with no success ${ }^{41}$.

Petr Bitsilli built up a similar image of the medieval man in his work Elements of Medieval Culture, where he gives a general description of a medieval man, his historical and cultural horizons and his perception of the world. Just as Karsavin did, Bitsilli in his studies drew on the Lives of the Saints, on literary masterpieces of the time, on the works of mystics and theologians, on "visions" and on records of the inquisition. He studied the works of many eminent scholars and philosophers of the time: Saint Augustine of Hippo, Francis of Assisi, Otto of Freising, Caesarius of Heisterbach, Hugh of Saint Victor, John Scotus Eriugena, Dante and others. Like Karsavin, Bitsilli included a large number of various elements in his perception of the mentality of a medieval person.

Bitsilli called the drive toward universality, which manifested itself everywhere: in science, in literature, in art - the central idea of the Middle Ages. A person of that time strove to embrace the world as a whole, to understand it as an "all-encompassing unity" and, if possible, to express this understanding in poetry, art or architecture. Polymathy was at the heart of of medieval creativity. Only universal knowledge was deemed true knowledge since everything in the world is connected to each other, everything is tied together ${ }^{42}$. The medieval man wanted to see unity and completeness in everything, not the variety or plurality of opinions, "there is no place in the world for opinions and personal views, there is only 'the truth' and every truth is dogma" 43 .

Petr Bitsilli singled out symbolism and hierarchism as two conditions of the unity of the world order in the mind of a medieval man. According to Bitsilli, symbolism and hierarchism is the formula of medieval worldview and the formula of the entire medieval culture. Thus, he furthered and supplemented the work of L.P. Karsavin. At the same time, unlike L.P. Karsavin, he did not limit symbolism to religion only, adding the idea of universal hierarchy as well. For a medieval mind, each thing or phenomenon had its own place in the hierarchy and had a strictly defined function, symbolizing something important.

Bitsilli agreed with the conclusion drawn by L.P. Karsavin that the symbolic meaning of a thing was its true meaning, from the point of view of medieval society. This is related to the peculiar "thingness" of the medieval mindset assigning an object existence to every abstract idea. Ultimately, the mind confused the symbol and the symbolized, and the difference between the abstract idea and its symbol was lost. The "Visions of Piers Plowman", a mystical didactic poem of the $15^{\text {th }}$ century, introduced the seven deadly sins in one of the scenes, "The author describes their manner and their clothing; some are gaunt, others are potbellied; these are strange abstractions with warts on their noses" 44 . The abstract idea of a sin is directly related to its symbolic expression - the defects of human appearance.

\footnotetext{
${ }^{40}$ Karsavin L.P. Monashestvo v Srednie veka... P. 174.

41 Karsavin L.P. Kultura srednikh vekov... P. 66.

42 Bitsilli P. M. Elementi srednevekovoy kulturi... P. 12-13.

${ }^{43}$ Ibid. P. 124.

44 Bitsilli P. M. Elementi srednevekovoy kulturi... P. 128.
} 
Petr Bitsilli also found practical expression of symbolism in the mind of a medieval man in the allegorical interpretations of the Scriptures by Saint Gregory the Great and Rabanus Maurus.

Symbolism and hierarchism are closely tied: every thing is a "small world" in which the "large world" looks for its reflection; however not every thing reflects (that is, expresses) it in full. Man reproduces the entire nature in himself. An animal reproduces only a part of it: it has only certain characteristics in common with man, etc ${ }^{45}$. Thus, man is in the center of the universe. The criterion of nobility or eminence is applicable to everything, even to inanimate objects ${ }^{46}$. Moreover, the earthly, social hierarchy is closely tied to the heavenly one, to the hierarchy of angelic ranks, examples of which the author finds in Clement of Alexandria, Saint Gregory the Great, John Scotus Eriugena and Guillaume d'Auvergne.

Petr Bitsilli's views on mysticism are also parallel to those of Karsavin. He also believed that the historical significance of mysticism lies in the fact that the one who learns is not limited to experience, but passes on his internal experience to others, freely interpreting the foundations of faith and church dogmas.

Symbolism and mysticism comprised one more important feature of the medieval mind. The result of relentless comparison of the earthly and heavenly world is the blurring of the line between the two. Here, we also see the coincidence of the conclusions drawn by Lew Karsavin and Petr Bitsilli. The characteristics of the object are transferred to the symbol in full. The symbol becomes the object of worship because it is endowed with the power of what it symbolizes. Hence, there is a tendency to attribute to certain things special magical power that is typical even of the educated. We see a twofold process: spiritual characteristics are ascribed to physical things, and physical - to spiritual ones . Thus the two worlds are bridged. The symbolic mindset overcomes the gap that separates them, according to P. M. Bitsilli. For all intents and purposes, there is no principal difference between them. "Material" and "spiritual" are only a scale: the material is "below" or "worse" than the spiritual, but cannot be imagined as separate from $\mathrm{it}^{47}$.

The basic features of the medieval mind are the longing for universality, symbolism, hierarchy, fascination with mysticism, which, according to P. M. Bitsilli, form certain facets of the medieval personality, certain insights into man himself and the world around him. At the same time, these are the crucial factors of man's behavior.

Drawing on the texts of medieval chronicles, in particular, the masterpieces of Salimbene di Adam, P.M. Bitsilli tried to reconstruct the perception of the world by a medieval man, his religious conscience, his historical sense. Here, the author arrived at an interesting insight: the Catholic practice of confession, which produced the habit of self-observation and self-analysis, played an important role in the spiritual growth of a medieval man ${ }^{48}$. According to P.M. Bitsilli, the world view of a person of that time was directly related to the Divine. "The world is whole only insofar as it entirely depends on God, insofar as it is His creation and reflection". Hierarchy and universality are only possible when the ladder of hierarchy is taken to its end, to its highest step, to God. "Things are drawn to each other

\footnotetext{
${ }^{45}$ Ibid.P. 54.

46 Ibid. P. 56.

47 Weber D. Significance of a religion in the Petr Bitsilli's research works // Vestnik of SaintPetersburg University. Philosophy and Conflict Studies. 2018. Vol. 34, iss. 1. P. 115-121.

48 Bitsilli P. M. Salimbene. Ocherki italyanskoy zhizni XIII veka. Odessa, 1916. P. 111.
} 
only for as long as they are drawn to God together"49. Hence, as P. M. Bitsilli aptly noted, is the incoherence of medieval works of literature and art that seems so strange to us. The author gives as an example the works of a $13^{\text {th }}$ century French chronicler Matthew of Paris, who listed events according to a pre-set plan. First, there are events of political history, then weather information, then the crops and prices on foodstuffs. The medieval man had his own reasoning that only he understood, and this reasoning had at least one element that was constant: the dependence of everything on God; everything else was secondary.

Petr Bitsilli made important comments with regard to the corporate mindset of a medieval man, whose meaning was revealed in the functioning of the commune, the most important institution of the Middle Ages. The essence of a commune lies in the "in-tuneness" of its members; the members of a commune form a seamless whole, the highest harmonious unity - a city, a corporation, a guild, a class. A man sought support and protection in a commune. Another important conclusion of the scholar is that the slow pace of life in medieval times made a person perceive the world as immovable, perceive it as a given, as the unchangeable result, and that such an approach to the world found its reflection in the art and culture of the Middle Ages. The lack of movement and the static imagery are the key features of medieval art.

As was already noted, the ideas of Karsavin and Bitsilli that were reviewed here have occasionally called forth harsh criticism. Among other aspects, the terminology they introduced was criticized ${ }^{50}$.

It should be pointed out that Russian historians of the Middle Ages of the late $19^{\text {th }}$ and the first decade of $20^{\text {th }}$ century were not all of one mind. They did not keep to exactly the same methodology of historical research, and there was no tendency among them to study the same problems or historical periods. However, they were united in their interest in the man in history, in the problems of the medieval worldview. Some scholars displayed more interest in the subject, while others were interested to a lesser degree. They were very close to formulating the specific academic problem: a study of Western European culture through the analysis of the peculiarity of medieval worldview. The prevalent term "medieval outlook" was also defined (the term "medieval worldview" was used less often). However, in considering the problem, authors only analyzed the views of certain historical personalities, the elite, the "best minds" of the Middle Ages. This was the key feature (or limitation) of their approach. We cannot say that this limitation will be overcome in full in subsequent studies. Nevertheless, the problem of the worldview of a medieval man reaches a new level in the works of historians of the $20^{\text {th }}$ century, especially in the works of L. P. Karsavin and P. M. Bitsilli.

Despite all of the above, the historians of the late $19^{\text {th }}$-first decade of the $20^{\text {th }}$ century made a significant contribution to the work on the subject. The interest in the man in history emerged in Russian medieval studies of the time. It is important to note that in analyzing the religiousness of an individual, the Russian scholars focused on the views of certain outstanding personalities, as a rule - those of the elite, the chroniclers and the

49 Bitsilli P. M. Elementi srednevekovoy kulturi... P. 88-89.

${ }^{50}$ Dobiash-Rozhdestvenskaya O. Religioznaia psihologiia...; Puzino I. Nekotoryie zamechaniia o knige Karsavina L.P. "Osnovy srednevekovoy religioznosti v XII-XIII vv., preimuschestvenno v Italii" // Istoricheskie izvestiya. 1916. N 1. P.94-101; Kareev N. Obschii religioznyi fond i individualnye religii // Russkie zapiski. 1916. N 9. P. 195-225. See more: Weber D. Issledovanie religioznoy kulturyi v trudah L. P. Karsavina // Religiovedenie. 2017. Vol. 1. P. 109-116. 
theologians. Political events interrupted the subsequent development in this area, and the formulation of a new historical paradigm, in turn, became a serious obstacle to creating a national school similar to the Annales School, for example.

The changes that took place in historiography starting in the late 1990s made the return to this issue possible, however, the achievements of the Annales School were used as the methodological basis, which is attested, among others, by the popularity in Russia of the works of J.Le Goff, while the research of national historians at the turn of the last century attracted much less attention.

\section{References}

Alpatov M. Krizis russkoy medievistiki v nachale XX veka, Problemi istoriografii. Voronezh, Voronezh University Press, 1960, pp.23-27. (In Russian)

Bitsilli P. Salimbene. Ocherki italyanskoy zhizni XIII veka. Odessa, Technik Publ., 1916, 389 p. (In Russian)

Bitsilli P. Ocherki teorii istoricheskoy nauki. Praga, Plamya Publ., 1925, 339 p. (In Russian)

Bitsilli P. Frantsisk Assizskiy i problema Renessansa, Sovremennyie zapiski, 1927, no. 30, pp. 520-537. (In Russian)

Bitsilli P. Elementi srednevekovoy kulturi. Saint Peterburg, Mifril Publ., 1995, 264 p. (In Russian)

Buzeskul V. Vseobschaya istoriya i ee predstaviteli. Leningrad, Izdatel'stvo AN SSSR Publ., 1929, part 1, 223 p. (In Russian)

Dobiash-Rozhdestvenskaya O. Religioznaya psihologiya srednevekovya v issledovaniyah russkogo uchenogo, Russkaya misl', 1916, no. 4, pp. 22-28. (In Russian)

Egorov D. Srednevekovaya religioznost i trud L.P. Karsavina. Istoricheskie izvestiya, 1916, no.2, pp. 85106 (In Russian)

Eicken H.v. Geschichte und System der mittelalterlichen Weltanschauung. Stuttgart, J.G. Cotta Publ., 1887, 822 S. (In German)

Ershova V. Dobiash-Rozhdlestvenskaya O. A. Leningrad, Leningrad University Press, 1988, 120 p. (In Russian)

Guerrier V. Katarina Sienskaya. Vestnik Evropy, 1892, vol. 5, no. 9, pp.5-56. (In Russian)

Guerrier V. Katarina Sienskaya. Vestnik Evropy, 1892, vol. 5, no. 10, pp.429-496. (In Russian)

Guerrier V. Ocherki razvitiya istoricheskoy nauki. Moskow, Universitetskaia tipografiya Katkov i Ko. Print, 1865, 59 p. (In Russian)

Guerrier V. Srednevekovoe mirovozzrenie. Ego vozniknovenie i ideal. Vestnik Evropy, 1891, no. 1, pp. 172196 (In Russian)

Guerrier V. Srednevekovoe mirovozzrenie. Ego vozniknovenie i ideal. Vestnik Evropy, 1891, no. 2, pp. 751781. (In Russian)

Guerrier V. Srednevekovoe mirovozzrenie. Ego vozniknovenie i ideal. Vestnik Evropy, 1891, no. 3. P. 5-29 (In Russian)

Guerrier V. Srednevekovoe mirovozzrenie. Ego vozniknovenie i ideal. Vestnik Evropy, 1891, no. 4, pp. 495552. (In Russian)

Guerrier V. Zapadnoe monashestvo i papstvo. Moskow, Tovarischestvo Pechatnya S. P. Yakovleva Print, 1913, 334 p. (In Russian)

Grevs I. Noviy trud po istorii srednevekovoy Italii. Zhurnal Ministerstva Narodnogo Prosvescheniya, 1913, no. 12, pp. 336-405. (In Russian)

Grevs I. Lik i dusha srednevekovya (po povodu vnov vyishedshih russkih trudov). Rassuzhdeniya po povodu treh knig - Dobiash-Rozhdestvenskaya O.A.Annali, 1922, no. 1, pp. 21-40. (In Russian)

Gurevich A. Kategorii srednevekovoy kulturyi. Moskow, Iskusstvo Publ., 1972, 350 p. (In Russian)

Gurevich A. Problemi srednevekovoy narodnoy kulturyi]. Moskow, Iskusstvo Publ., 1981, 360 p. (In Russian)

Gutnova E. Sorok let sovetskoy medievistiki i ee ocherednyie zadachi. Srednie veka, 1957, iss. 10, pp.3-24. (In Russian)

Ivanova T. Dilemmi zapadnoevropeyskogo srednevekovya $\mathrm{v}$ istoricheskoy kontseptsii V.I.Guerrier, Uchenyie zapiski Kazanskogo gosudarstvennogo universiteta, 2009, vol. 151, book 2, part 1, pp. 145-156. (In Russian)

Kaganovich B. Bitsilli P. M. i ego kniga "Elementi srednevekovoy kulturi". St. Petersburg, Mifril Publ., 1995, 242 p. (In Russian) 
Kareev L. Po povodu odnogo issledovaniya srednevekovyih nauchnyih dvizheniy. Russkoe bogatstvo, 1913, no. 6, pp.333-340. (In Russian)

Kareev N. Obschiy religioznyiy fond i individualnie religii (po povodu "Osnov" L. P. Karsavina i "Valdenskogo dvizheniya” A. G. Vulfiusa). Russkie zapiski, 1916, no. 9, pp. 195-225. (In Russian)

Karsavin L. Mistika i ee znachenie v religioznosti srednevekovjya. Vestnik Evropy, 1913, no. 8, pp.118-135. (In Russian)

Karsavin L. Monashestvo v Srednie veka. Moskow, Tipografiia Akts; Brokgauz-Efron Print., 1912, 110 p. (In Russian)

Karsavin L. Osnovy srednevekovoy religioznosti v XII-XIII vekakh, preimuschestvenno v Italii. St. Petersburg, Tipografia M. A. Aleksandrova, 1915, 360 p. (In Russian)

Karsavin L. Kultura srednih vekov. Petrograd, Ogni Publ., 1918, 224 p. (In Russian)

Karsavin L. Ocherki religioznoi zhizni v Italii XII-XIII vekov. St. Petersburg, Tipografiia M. A. Aleksandrova, 1912, 884 p. (In Russian)

Karsavin L. Simvolizm myshleniia i ideia miroporiadka v srednie vekakh. XII-XIII vv. Nauchnyiy istoricheskiy zhurnal, 1914, vol. 1, iss. 2, pp. 10-28. (In Russian)

Karsavin L. Vvedenie v istoriu (Teoriia istorii). Petrograd, Nauka i shkola Publ., 1920, 78 p. (In Russian)

Krom M. Istoricheskaia antropologiia. St. Petersburg, European University at St. Petersburg Press, 2004, 216 p. (In Russian)

Kudryavtsev P. Lektsii. Sochineniia. Moskow, Nauka Publ., 1991, 344 p. (In Russian)

Kupriyanov A. Istoricheskaia antropologiia v Rossii: problemy stanovleniia. Istoricheskie issledovaniia $v$ Rossii (tendentsii poslednikh let), 1996, no. 4, pp.366-385. (In Russian)

Laurent P. Études sur l'histoire de l'humanité. Christianisme. T. 4. Gand, chez H. Hoste Publ., 1855, 800 p.

Lévy-Bruhl L. La mentalité primitive. Paris, Librairie Félix Alcan Publ., 1925, 537 p.

Mogilnitskiy B. G. Politicheskie i metodologicheskie idei russkoi liberalnoi mediyevistiki serediny 70-kh godov XIX v. - nachala 900-kh godov. Tomsk, Tomsk University Press, 1969, 408 p. (In Russian)

Puzino I. Nekotoryie zamechaniia o knige Karsavina L.P. "Osnovy srednevekovoi religioznosti v XIIXIII vv., preimuschestvenno v Italii“. Istoricheskie izvestiya, 1916, no. 1, pp.94-101. (In Russian)

Seleznev R.S. Mentalnaia istoriia Srednevekov'ia v issledovaniyakh pervykh russkikh mediyevistov vtoroy poloviny XIX v.: istoki i zarozhdenie problematiki. Rossiia i mir: panorama istoricheskogo razvitiia: sbornik nauchnykh statey, posviashchennyy 70-letiyu istoricheskogo fakulteta Uralskogo gosudarstvennogo universiteta im. A. M. Gorkogo. Ekaterinburg, NPMP Volot Publ., 2008, pp. 48-56. (In Russian)

Shakhnovich M. The activity of the commission on the history of the communist academy (Moskow, 19281930) and the study of religiosity in USSR. Religiski-filozofiski raksti. 2017, vol.XXIII, pp.9-25. (In Russian)

Shkuratov V. Istoricheskaia psihologiia na perekrestkakh chelovekoznaniia. Odissey. Chelovek v istorii, 1991, pp.97-108. (In Russian)

Vaynshteiyn O. Istoriografiia srednikh vekov v sviazi s razvitiem istoricheskoi myisli ot nachala srednkih vekov do nashikh dney. Moscow; Leningrad, Sotsekgiz Publ., 1940, 376 p. (In Russian)

Vaynshtein O. Istoriya sovetskoy medievistiki. Leningrad, Nauka Publ., 1968, 423 p. (In Russian)

Vahromeeva O. (2004) Chelovek s otkryityim serdtsem. Avtobiograficheskoe i epistolyarnoe nasledie I. M. Grevsa (1860-1941). St. Petersburg, St. Peterburgskii filial Arhiva Rossiiskoi akademii nauk Publ., 372 p. (In Russian)

Vasileva M. A. Srednevekovaia Italia i spor o "srednem cheloveke": polemika P. M. Bicilli s L. P. Karsavinyim. Rossiya - Zapad - Vostok. Literaturnyie i kulturnyie sviazi. N 2. St. Petersburg, Institut russkoi literaturi RAN Publ., 2014, pp. 50-64. (In Russian)

Weber D. Issledovanie religioznoi kulturyi v trudakh L. P. Karsavina. Religiovedenie, 2017, no. 1, pp. 109-116. (In Russian)

Weber D. Significance of a religion in the Petr Bitsilli's research works. Vestnik of Saint Petersburg University. Philosophy and Conflict Studies. 2018, vol.34, iss. 1, pp.115-121. (In Russian)

Weber D. The Religious Studies on the Eve of Totalitarianism. The Issue of Reformation. Religiski - filozofiski raksti, 2017, vol. XXIII, pp.69-83.

Yastrebitskaya A. Povsednevnost' i materialnaia kultura srednevekov'ia v otechestvennoi medievistike, Odissey. Chelovek v istorii, 1991, pp. 84-103. (In Russian)

Received: May 28, 2018

Accepted: September 10, 2018 